Jusmal lemiah
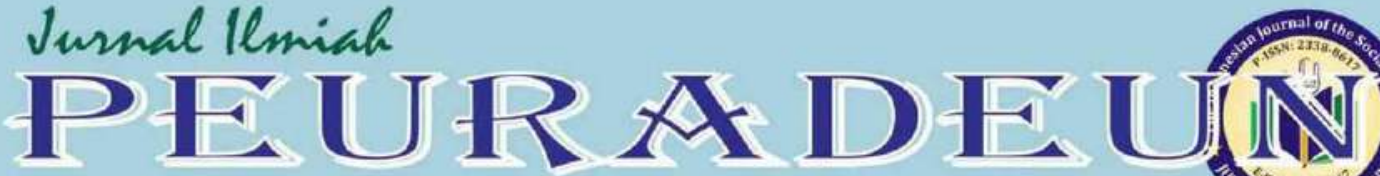

Vol. 6, No. 1, January 2018

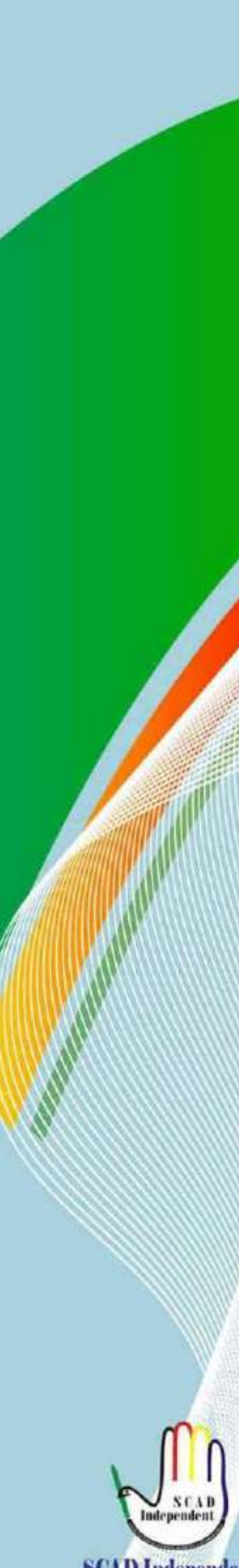

SCAI) Independent Accreditatioa by HO since 2014 $\bigodot$ Copernicus Publications

\section{III}

The Indonesian Journal of the Social Sciences www.journal.scadindependent.org Dot Prefix Number: 10.26811

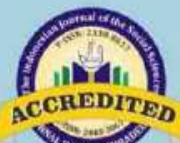

ACCREDITED - B" by the Ministry of Risteklikti from Oetaber 30, 2017 until Oetober 30, 2022

\section{Clarivate Analytics}

Emerging Sources Citation Index Web of Science ${ }^{\mathrm{TM}}$

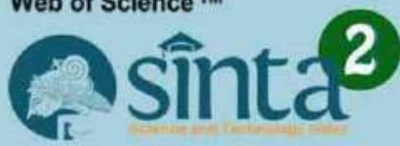
INDEX $\circledast$ COPERNICUS 


\title{
PARENTS' INVOLVEMENT IN IMPROVING CHARACTER OF CHILDREN THROUGH MATHEMATICS LEARNING
}

\author{
Sabaruddin ${ }^{1} \&$ Rosidar Mansor ${ }^{2}$ \\ ${ }^{1}$ Dapartemen of Mathematics Education, Faculty of Tarbiyah, IAIN Langsa Aceh, Indonesia \\ ${ }^{2}$ Faculty of Education and Human Development, Sultan Idris Education University (UPSI), \\ Perak, Malaysia \\ ${ }^{1}$ Contibutor Email: sabaruddin.fazia@gmail.com
}

Received: Jun 25, 2017

Accepted: Nov 11, 2017

Published: Jan 28, 2018

Article Url: http://journal.scadindependent.org/index.php/jipeuradeun/article/view/178

\begin{abstract}
The aim of this paper is to discuss parental involvement to the development of children character in mathematics learning. Parents are very important in improving children character by spending more time at home together, awareness and concern of parents are very influential towards the formation of character and academic performance of children. Mathematics education can be seen as a situation or the nature or even the value of synergies with character development. The achievements of pupils in mathematics and their participation to a higher level in mathematics are a reflection of the attitudes and aspirations of their parents. This study discusses parents' involvement in improving the character of children through mathematical learning in the elementary school. This study describes the parent's knowledge and their character education, the concern towards their child's math skills, the difficulties of children in mathematics and the cooperation of the school and parents in improving the character of children at the elementary school.
\end{abstract}

Keywords: Parents' Involvement, Characters and Mathematics Learning 


\section{A. Introduction}

Family is the first school for the children, the role of parents is very important as a teacher. The Indonesian school system undoubtedly needs considerable work and there is no quick-fix answer to the problem. But, parents can help, and even when children in are highly competitive, wonderful academic institutions, parents have a responsibility to be involved and help their children academically. No one expects that parental involvement will fix the achievement gap or the failures of our education system as a whole, but their involvement is crucial (Mizal, 2014).

The character education integrated into learning various areas of study can provide a meaningful experience for students as they understand, pursue, and creating through the process of learning. The character building of students become a primary responsibility for teachers in the school, parents at home, and people in the neighborhood. (Lewis \& Ponzio, 2016; Nurhasanah \& Qathrin Nida, 2016; Zuchdi, 2010). Ministry of education forms a race of character education program, which has been implemented throughout schools in Indonesia. New curriculum with emphasis on competency and character, this system of learning in the curriculum of all integrated with the educational character and thematic learning system. At the stage of primary education to implement fully carry out thematic learning system, while at the secondary school education in turn mixed with thematic subjects (Zuchdi, 2013).

Nowadays, the formation of students character is only through learning education character only, even Mathematics there is no relation to the formation of character student (Melinda Bier, 2005). A presumption is not very appropriate to the teaching methods of mathematics consisting of the value of mathematics and mathematical education value (Bishop Seah, 2002). Therefore, to form the character of the students, does not have to go through one subject only, but can be also integrated into each subject, including at mathematics (Prayitno \& Manullang, 2011; Muslich, 2011). This is in accordance with a statement of Ahmad Sudrajat (2010) that education can be a character in integration in learning in each subject. Learning related to norms or values at each subject should be developed, implemented, 
associated with the context of life every day. Therefore, learning the values of character not only in the cognitive situation but touched on the development and practice of the real daily life of students in the community.

Agus Prabowo and Pramono Sidi (2010) also stressed that learning math is not just working on math materials, but also educating to create and build a character. Learning math is not just to support the development of the cognitive aspect, but also to expand the aspect of cognitive and Psychomotor (Gladwell, 2009). Wan Zah et al. (2005) argue that the teaching approach which focuses on instilling math will make teaching more effective, interesting, meaningful and useful to students. The value of mathematics will raise interest in math, understanding of the importance of mathematics in life and helps students the mathematical strength better and form a student character suits expected.

The math is considered difficult and only pressing to cognitive only. Identical with numbers and mathematical calculations, and the society also considers that mathematics does not implement the values and character of students. The role of mathematics in developing students character in the context of education had extensive coverage, as described by Mulyasa (2011) that character education is not just a related with right and wrong but how ingrained habits about the good things in life, so that students have a high level of awareness and understanding as well as concern and commitment to apply the virtues in their daily lives.

Education value and educational character two things contiguous (Mohd Uzi, 2011). Value is personal preference-related standards individuals to consider the interests or benefits of a thing for their own to think (Chin \& Lin, 2001). There are studies that focused values practiced in the classroom, i.e. during the teaching and learning of mathematics. This study shows that the experience of mathematical education in school influence adoption among students (Bishop, Fitz Simons, Seah \& Clarkson, 2001).

Teachers practice in the application of curriculum 2013, character in teaching mathematics very challenging with some problems such as teacher education have to spend based on the syllabus and yet the availability of guidelines implementation of character in learning math. The result of 
collaborative character education efforts will be a kind of synergy that has the ability to combat negative behavior's, inspire and encourage students, and build strong caring communities (Lewis \& Ponzio, 2016).

\section{B. Method}

This study used Mixed Method Research. The methods and methodologies for conducting research involving collect, analyze and integrate quantitative and qualitative research in a study or program (Craswell \& Clark, 2011). This study uses methods triangulation design as shown in Figure:

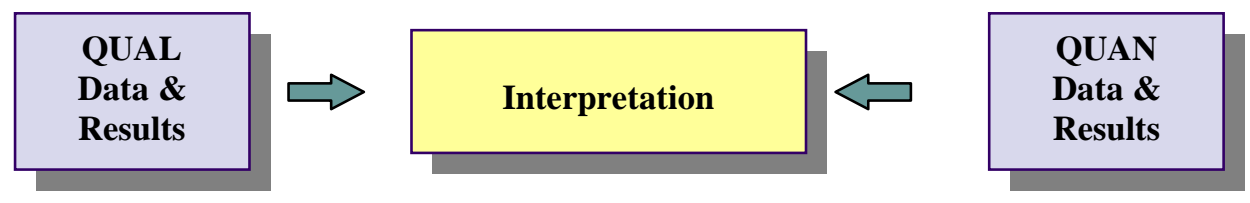

Figur 1. Triangulation Design (Craswell \& Clark, 2011).

This data analysis uses descriptive statistics for the conclusions of each parent role assessment. Analysis of this data includes: developing a notes field, categorizing data, giving a code on the data, developing and entering data into the format of the analysis, and develop questions to collect data. While data analysis is done after the data collected include collecting and administering the code in chronological order according to the time of data collection, data collection grouping in one format category classification in accordance with the code. Flow analysis of the qualitative data was used in this study the following chart shown in Figure:

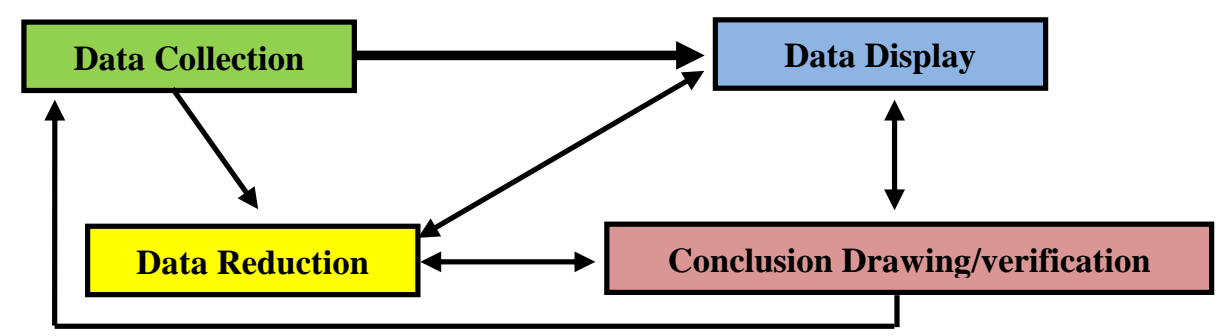

Figur 2. Data Flowchart (Milles \& Hubermen, 2009). 


\section{Research Finding \& Discussion}

This study involves about 700 parents in giving the perception of the role in character education and support of the teaching and learning of mathematics. Each school engage 10 people parents willing to help researchers in include their opinion through a questionnaire and interview that was completed at the outset.

Table 1. Tabulation of parent roles

\begin{tabular}{llllll}
\hline \multirow{2}{*}{ No } & \multicolumn{1}{c}{ Statement } & \multicolumn{2}{c}{ Agree } & \multicolumn{2}{c}{ Not Agree } \\
\cline { 2 - 5 } 1 & $\sum$ & $\%$ & $\sum$ & $\%$ \\
\hline & $\begin{array}{l}\text { I'm concerned with the child's math } \\
\text { skills }\end{array}$ & 514 & 73 & 186 & 27 \\
\hline 2 & $\begin{array}{l}\text { The math lessons that my child has too } \\
\text { difficult }\end{array}$ & 449 & 64 & 251 & 36 \\
\hline 3 & $\begin{array}{l}\text { I provide time to guide children to learn } \\
\text { math at home }\end{array}$ & 585 & 84 & 115 & 16 \\
\hline 4 & $\begin{array}{l}\text { I'm more concerned with math lessons } \\
\text { than any other lesson }\end{array}$ & 159 & 23 & 541 & 77 \\
\hline 5 & $\begin{array}{l}\text { My children have difficulty } \\
\text { understanding mathematics }\end{array}$ & 469 & 67 & 233 & 33 \\
\hline 6 & $\begin{array}{l}\text { I feel annoyed if my child has trouble } \\
\text { learning math }\end{array}$ & 391 & 56 & 309 & 44 \\
\hline
\end{tabular}

Parent's judgment of children's mathematical proficiency shows that as 514 parents (73\%) expressed doubt about their child's mathematical skills, the rest as many as 186 person parents $(27 \%)$ said no wavering against the mathematical proficiency of their children. It can be concluded that the level of indecision mathematical lessons against the parents of the children is very high. This indicates that there is a problem with the mathematical lesson at the elementary school, from data document show that is mathematical achievement is obtained school is lower than in other lessons.

The opinion of related to mathematics lessons that became the difficulties of children, found to be as 449 parents (64\%) stated that mathematics lessons that difficulty of children, such as 251 parents $(36 \%)$ stated not on the statement of mathematics lesson are a difficult lesson for their child. Most parents feel the difficulty in learning their children's mathematics, especially in solving tasks often given by teachers. The 
parents said is assignments given the task of child pressure and fear of math. Lange, T., \& Meaney, T. (2010) suggest homework acted as an indicator of their ability in mathematics and was considered an unnecessary intrusion into their busy, out-of-school lives. This intrusion became a burden, if the children were unclear about what was required or if the level of work was too easy.

The provision of time to guide the children learning mathematics at home was found to be as 585 parents $(84 \%)$ responded agree, the rest was 115 parents $(16 \%)$ who declared no time to guide the children to study mathematics at home. Most of the parents provide the time for children to learn mathematics. Most parents realize that in addition to reading and telling children it can improve children's knowledge, so giving attention to math skills for child is also important. Every child and adult needs to know and understand mathematics. It's part of our everyday life, we all "do the math" Everywhere and every time (Paul Giganti, 2014). Parents' guide their children's mathematics by accustomed to positive mathematics, telling stories about mathematics, giving mathematical toys and explaining the purpose of math in daily activity.

Mathematics is not a lesson priorities for parents in primary school, this is indicated by the data, there were 541 parents $(77 \%)$ who said it was not on statement is more concerned with mathematics than other subjects, while there are only 159 parents $(23 \%)$ who said so in statement is more concerned with the math lessons of other subjects. Mathematics is a part of many subjects in the primary school. Therefore, the mathematics is not a priorities lesson for parent.

The statement was irritated when children have trouble learning math found a total of 391 parents (56\%) said yes, while a total of 309 parents $(44 \%)$ said no. It showed that many parents who feel that mathematics is an important lesson for the other adjustments, a lot of parents who are upset when their children have trouble learning math. Math Trouble in pupils Elementary School usually Has difficulty using math in real life, doesn't understand the concept of "more than" or "less than", struggles to learn and remember basic math facts, such as $5+5=$ 
10, doesn't make the connection between related math facts or "fact families," such as $5+5=10$, so $10-5=5$, has trouble recognizing written numbers (also known as numerals), Still uses fingers to count instead of doing the calculation in her head and doesn't know how to calculate percent from discount in the market.

Parents said yes to the statement of my child having difficulty understanding the material taught mathematics teacher at the school, there were a total of 469 data parents $(67 \%)$ who said yes and a total of 233 parents $(33 \%)$ who said no. It can be concluded that primary school pupils are still experiencing difficulties in learning mathematics. Parents feel the difficulty in accompanying their children in character building with math activities, what more parents and children feel the math of something difficult.

As your child's first teacher you can be an effective partner for your child's learning through simply how you talk and play with your child. Your home is a great place for you to begin to explore and "talk" mathematics with your child. Incorporating math activities and language into familiar daily routines will show your child how math works in his everyday life and provide him with a safe environment in which to take risks by trying new things (Kuttan, 2013).

Although parents can be a positive force in helping children learn math, they also can undermine their children's math ability and attitudes by saying things such as: "Math is hard," or "I'm not surprised you don't do well in math, I didn't like math either when I was in school," or "I wasn't very good in math and I'm a success, so don't worry about doing well." Although you can't make your child like math, you can encourage her to do so, and you can take steps to ensure that she learns to appreciate its value both in her everyday life and in preparing for her future.

The same problem is also expressed by Tarzimah, he found that students were reported to have difficulties in mathematics problem solving (Tarzimah \& Thamby, 2010). Should parents follow Diezmann's steps is before they start school, most children develop an understanding of addition and subtraction through everyday interactions. Learn what informal activities give children a head start when they start learning math in school (Diezmann, 2001). 
Home is a great place for you to begin to explore and "talk" mathematics with your child. Incorporating math activities and language into familiar daily routines will show your child how math works in his everyday life and provide him with a safe environment in which to take risks by trying new things.

\section{Conclusion}

It is evident that children use mathematics and numeracy from a very young age; they have a need to learn about mathematics in order for them to be able to make sense of and live in their world. This report shows that there is research evidence to support that children benefit from an early approach to mathematics both at home from their parents and from having access to a skilled workforce of practitioners. Mathematical experiences for young children should be meaningful and purposeful in order to allow the child to use familiar concepts. Research shows that parents focus on mathematics, most parents are very concerned about their child's achievements especially in the field of mathematics, and they also expect improvement of their child's character through mathematical learning.

\section{Bibliography}

Abtahi, M., \& Battell, C. (2017). Integrate Social Justice Into the Mathematics Curriculum in Learning. Jurnal Ilmiah Peuradeun, 5(1), 101-114.

Acosta, M. (2016). Paradigm Shift in Open Education and E-Learning Resources as Teaching and Learning in Philippines. Jurnal Ilmiah Peuradeun, 4(2), 161-172.

Bakar, A., \& Anwar, A. (2015). Learning Materials in Character Education. Jurnal Ilmiah Peuradeun, 3(3), 405-416.

Bier, Melinda C; Berkowitz \& Marvin W, (2005), what works in character education, Leadership for Student Activities, Reston, Vol. 34, Num. 2, October 2005, p. 7-13.

Bishop, A. J., \& Seah, W. T. (2002). Values, mathematics and society: Making the connections. Retrieved August 1, 2010.

Bishop, A. J., Fitzsimons, G., Seah., W. T. \& Clarkson, P. (2001). Do Teachers Implement Their Intended Values in Mathematics Classrooms? 
Proceedings of the 25th Conference of the International Group for the Psychology of Mathematics Education (Vol. 2, pp. 169-176). Utrecht, The Netherlands: Freudenthal Institute.

Creswell, J. W., \& Plano Clark, V. L. (2011). Designing and Conducting Mixed Methods Research (2nd ed.). Los Angeles, LA: Sage.

Diezmann, C., \& Yelland, N. J. (2000). Developing mathematical literacy in the early childhood years. In Yelland, N.J. (Ed.), Promoting meaningful learning: Innovations in educating early childhood professionals. (pp.47-58). Washington, DC: National Association for the Education of Young Children.

Hamdan, Abdul Rahim and Zahari, Azharul Nizam. (2010). Konsep Pendidikan Bersepadu Serta Penerapan Nilai-Nilai Murni Dalam Pengajaran Matematik Menengah Rendah. Konsep Pendidikan Bersepadu Serta Penerapan Nilai-Nilai Murni Dalam Pengajaran Matematik Menengah Rendah.

Kaylene, P., \& Rosone, T. L. (2016). Multicultural Perspective on the Motivation of Students in Teaching Physical Education. Jurnal Ilmiah Peuradeun, 4(1), 115-126.

Lange, T., \& Meaney, T. (2010). Children's perspectives on mathematics homework. In Seventh Swedish Mathematics Education Research Seminar (MADIF-7) (pp. 135-145). Linköping universitet at Linköping: Linköping universitet.

Lewis, M. \& Ponzio, P. (2016). Character Education as the Primary Purpose of Schooling for the Future. Jurnal Ilmiah Peuradeun, 4(2), 137-146.

Meaney, T., Helenius, O., Johansson, M.L., Lange, T., Wernberg, A. (Eds.) (2014), Mathematics Education in the Early Years, Results from the POEM2 Conference, Springer Link.

Miles, M. B., \& Huberman, A. M. (1994). Qualitative data analysis: An expanded sourcebook (2nd ed.). Thousand Oaks, CA: Sage.

Mizal, B. (2014). Pendidikan dalam Keluarga. Jurnal Ilmiah Peuradeun, 2(3), 155-178.

Mohd Uzi Dollah \& Lim, C. S. (2009). Penerapan Nilai Pendidikan Matematik Dalam Pengajaran Matematik Di Sekolah Menengah. Jurnal Sains dan Matematik.Vol.1 No.2 (29-40).

Mulyasa, E. (2011). Menjadi Guru Profesional. Bandung: Remaja Rosdakarya.

Muslich, Mansur. (2011). Pendidikan Karakter. Jakarta: Bumi Aksara.

Nata, Abuddin (2001). Pemikiran Para Tokoh Pendidikan Islam: Seri Kajian Filsafat Pendidikan Islam. Jakarta: Raja Grafindo Persada. 
Nurhasanah, N., \& Nida, Q. (2016). Character Building of Students by Guidance and Counseling Teachers Through Guidance and Counseling Services. Jurnal Ilmiah Peuradeun, 4(1), 65-76.

Prabowo, Agus \& Sidi, Purnomo. (2010). Memahat Karakter Melalui Pembelajaran Matematika. Proceedings of The 4th International Conference on Teacher Education, Join Conference UPI \& UPSI, Bandung, Indonesia, 8 - 10 November 2010.

Prayitno \& Belferik, M. (2011). Pendidikan Karakter dalam Pembangunan Bangsa. Medan: Penerbit Pascasarjana Universitas Negeri Medan.

Saefullah, Avip, (2003). Lembaga Pendidikan Indonesia Gagal Membangun Karakter Bangsa. Harian Kompas: Selasa, 18 Maret 2003, P. 9, Colum 1.

Salami, S. (2015). Implementing Neuro Linguistic Programming (NLP) in Changing Students' Behavior: Research Done at Islamic Universities in Aceh. Jurnal Ilmiah Peuradeun, 3(2), 235-256.

Tabrani. ZA \& Masbur, M. (2016). Islamic Perspectives on the Existence of Soul and Its Influence in Human Learning (A Philosophical Analysis of the Classical and Modern Learning Theories). Jurnal Edukasi: Jurnal Bimbingan Konseling, 1(2), 99-112.

Tarzimah \& Thamby. (2010), Students' Difficulties in Mathematics Problem-Solving: What do they Say?. International Conference on Mathematics Education Research 2010 (ICMER 2010). Procedia Social and Behavioral Sciences 8 (2010) 142-151.

Vitoria, L., \& Monawati, M. (2016). Improving Students' Problem Solving Skill in Mathematics Through Writing. Jurnal Ilmiah Peuradeun, 4(2), 231-238.

Walidin, W., Idris, S \& Tabrani. ZA. (2015). Metodologi Penelitian Kualitatif dan Grounded Theory. Banda Aceh: FTK Ar-Raniry Press

Wan Zah Wan Ali, Sharifah Kartini Said Husain, Habsah Ismail, Ramlah Hamzah, Mat Rofa Ismail, Mohd. Majid Konting \& Rohani Ahmad Tarmizi. (2005). Kefahaman Guru Tentang Nilai Matematik. Jurnal Teknologi, Universiti Teknologi Malaysia 43(E)(45-62).

Yusoff, M. Z. M., \& Hamzah, A. (2015). Direction of Moral Education Teacher To Enrich Character Education. Jurnal Ilmiah Peuradeun, 3(1), 119-132.

Zuchdi, D. dkk. (2013). Model Pendidikan Karakter: Terintegrasi dalam pembelajaran dan Pengembangan Kultur. Yogyakarta: UNY Press. 